\title{
Tipologi Inovasi Sektor Publik Pada Tiga Program Inovatif Pemerintah Daerah Kota Surabaya \\ (Tinjauan Reflektif terhadap Tiga Inovasi Pelayanan Publik \\ Pemerintah Kota Surabaya Tahun 2018)
}

\author{
Kristian Widya Wicaksono ${ }^{1}$
}

\begin{abstract}
The decentralization policy in Indonesia puts the local government as the main actor to bring their community to achieve their common purpose and goal. Thus, the local government needs to be empowered so they will have a capacity to make a significant breakthrough in their decisions and actions. In line with that need, the Indonesia central government issues a law called local innovation to develop the performance of government operation and enable the acceleration of people wealth improvement. The purpose of local innovation law is also to protect local government innovation and increase in number of local government innovations. Besides the law instrument, the attention from central government by recognizing the innovative program that has been done by local government is also very important. Therefore, the Ministry of Administrative Reform provides an award for local government innovation as an incentive for local government creative efforts.
\end{abstract}

This study is conducted to explore the valid concept of public sector innovation. Furthermore, this paper will provide a reflective analysis of the three innovative programs initiated by the local government in Surabaya City based on the perspective of typologies of public sector innovation. An exploratory approach is utilized in this paper to gain valid understanding about the concept of public sector innovation and its typologies in the local level.

The result of this study shows that innovation and public sector innovation is a set of academic concepts which related with newness and change and it has a serious intent to improve the quality of input, product and its impact on the customer needs. Moreover, the three innovative programs of Surabaya City local government are fulfilled four criteria of the typologies of public sector innovation, which are the creation of new service, process innovation, administrative innovation, and conceptual innovation.

Keywords: Innovation, newness, breakthrough, and change

1 Dosen pada Program Studi Administrasi Publik FISIP Unpar dan Mahasiswa Program Doktor pada Departemen Ilmu Politik, Universitas Tunghai, Taiwan. e-mail: kristian.widya@unpar.ac.id 


\section{Latar Belakang}

Kebijakan Pemerintahan Daerah di Indonesia setelah terjadi reformasi tahun 1998 terus mengalami penyempurnaan. Dimulai dengan diterbitkannya Undang-Undang No. 22 Tahun 1999, kemudian diubah menjadi UndangUndang No. 32 Tahun 2004 dan disempurnakan lebih jauh di dalam Undang-Undang No. 23 Tahun 2014. Undang-Undang yang disebutkan terakhir pun sudah memasuki Perubahan Kedua yang diundangkan di dalam Undang-Undang No. 9 Tahun 2015. Hal ini menunjukan bahwa bangsa Indonesia terus berproses ke arah hasil pelaksanaan kebijakan Pemerintahan Daerah yang diharapkan akan membawa dampak signifikan bagi peningkatan kesejahteraan masyarakat. Meskipun masih terdapat sejumlah perdebatan yang tidak terhindarkan mengenai kebijakan Pemerintahan Daerah di Indonesia, namun setidaknya dari waktu ke waktu, para pengambil keputusan bisa mempelajari dan membenahi kelemahan-kelemahan yang perlu diperbaiki dari Undang-Undang yang mengatur tentang Pemerintahan Daerah agar semakin memenuhi harapan pada proses implementasi dan dampak yang dihasilkannya bagi masyarakat.

Lebih lanjut, salah satu hal yang cukup mendasar dalam kebijakan Pemerintahan Daerah di Indonesia adalah desentralisasi. Pada Pasal 1 Ayat 8 Undang-Undang No. 23 Tahun 2014 disebutkan bahwa desentralisasi adalah penyerahan Urusan Pemerintahan oleh Pemerintah Pusat kepada daerah otonom berdasarkan Asas Otonomi. Berdasarkan definisi tersebut maka dapat dinyatakan bahwa salah satu aktor kebijakan yang berperan penting untuk mengantarkan masyarakat di daerah dapat merasakan dampak kesejahteraan dari pelaksanaan kebijakan Pemerintahan Daerah adalah Pemerintah Daerah itu sendiri.

Sebagai salah satu aktor penting, Pemerintah Daerah sesuai kewenangan yang dimilikinya diharapkan mampu menghasilkan keputusan dan tindakan yang tepat untuk mengatasi masalah dan memenuhi kebutuhan masyarakat di daerahnya. Sejalan dengan hal tersebut, kita menyadari bahwa dibutuhkan upaya yang serius untuk mengangkat kualitas keputusan dan tindakan Pemerintah Daerah agar lebih efektif dan efisien melalui terobosanterobosan inovatif. Secara lebih tegas dapat dinyatakan bahwa inovasi dibutuhkan oleh Pemerintah Daerah untuk meningkatkan kualitas keputusan dan tindakan yang dihasilkannya agar dampaknya dapat meningkatkan kesejahteraan masyarakat lokal.

Pada mulanya kajian mengenai inovasi lebih cenderung dibahas oleh akademisi dan praktisi di sektor bisnis. Hal ini dikarenakan organisasi sektor bisnis memiliki tingkat formalisasi yang lebih rendah jika dibandingkan dengan organisasi publik sehingga banyaknya aturan menyebabkan organisasi sektor publik tidak terlampau leluasa untuk berinovasi (Suwarno, 2011). Selain itu, organisasi bisnis dihadapkan dengan permasalahan keterbatasan sumberdaya yang mendesak sehingga diperlukan solusi yang tepat untuk mengatasi permasalahan tersebut. Maka sebagai konsekuensinya diupayakanlah agar terjadi inovasi untuk meningkatkan efisiensi.

Namun, jika ditelusuri lebih lanjut inovasi tidak bisa selalu dikaitkan dengan bagaimana sumberdaya diolah dan dimanfaatkan untuk menghasilkan sebuah produk. Sebab, inovasi juga juga dapat terjadi pada kebaruan produk yang dihasilkan bahkan pada bagaimana cara untuk mendapatkan sumberdaya sebagai masukan (input) bagi organisasi. Apabila kita memetakan skema sebuah sistem yang terdiri dari tiga bagian yaitu: masukan, proses dan keluaran, maka inovasi dapat dilakukan pada ketiga bagian tersebut. Hal ini sejalan dengan yang dikemukakan oleh Freeman bahwa inovasi terkait dengan produk baru, proses dan sistem yang dikembangkan dalam sebuah organisasi (Freeman, 1997).

Selain itu, belakangan inovasi juga tidak hanya terjadi pada sektor bisnis saja sebab sebagaimana yang sudah ditegaskan sebelumnya bahwa pada sektor publik, inovasi juga ternyata dibutuhkan. Bahkan inovasi sektor publik diyakini bukan lagi hal yang baru lagi (Mulyono, 2008). Konsep kewirausahaan (entrepreneur- 
ship) yang diperkenalkan oleh Osborne \& Gaebler (1992) merupakan salah satu indikasi bahwa semangat kewirausahaan yang menjadi pendorong inovasi sudah memiliki rekam jejak yang cukup lama pada kajian sektor publik. Lebih jauh lagi, bahwa meskipun kedua penulis tersebut tidak menyatakannya secara implisit mengenai hubungan semangat kewirausahaan dan inovasi, namun pada bagian index buku yang ditulis oleh Osborne \& Gaebler, kata inovasi disebutkan sebanyak sebelas kali. Hal ini menandakan bahwa secara eksplisit Osborne \& Gaebler melihat adanya hubungan antara semangat kewirausahaan dan inovasi.

Dalam tulisan yang lain, ada pula ahli yang berpendapat bahwa konsep kewirausahaan dapat dinyatakan sebagai landasan ideal bagi operasionalisasi kosep inovasi (Land \& Jarman, 1992). Baik kewirausahaan maupun inovasi mengarah pada pengembangan kebaruan-kebaruan terutama dalam hal manajerial pemerintahan serta penyediaan barang dan jasa di sektor publik. Dari sisi praktek, pada dekade 1980an banyak diulas mengenai kepemimpinan Perdana Menteri Inggris, Margareth Tatcher dan Presiden Amerika, Ronald Reagan yang dianggap sukses melakukan sejumlah terobosan dalam praktek pemerintahan yakni mengefisiensikan anggaran dan merubah cara kerja organisasi publik menjadi lebih produktif (Hughes, 2003).

Meskipun demikian tetap perlu dipahami bahwa kewirausahaan dan inovasi adalah dua konsep yang berbeda. Dalam pemahaman penulis jika kita merujuk pada pendapat Osbrone dan Gaebler bahwa kewirausahaan adalah semangat (spirit) yang melandasi inovasi. Sedangkan inovasi sendiri merupakan bentuk operasional dari konsep kewirausahaan yang mengarah pada menciptakan gagasan dan melaksanakan tindakan nyata untuk mewujudkan perubahan yang berorientasi pada kebaruan.

Di Indonesia, Pemerintah berupaya untuk menyediakan dukungan regulasi yang optimal bagi berkembangnya inovasi khususnya inovasi pada tingkat local. Pada Undang-Undang No. 23 Tahun 2014 yang mengatur Pemerintahan Daerah terdapat bab yang secara khusus meng- atur mengenai Inovasi Daerah yaitu Bab XXI. Kemudian sesuai dengan amanat Bab XXI pasal 390 pada Undang-Undang tersebut, maka Pemerintah Indonesia menerbitkan Peraturan Pemerintah No. 38 Tahun 2017 yang secara spesifik mengatur mengenai inovasi daerah. Adapun yang dimaksud sebagai inovasi daerah di dalam peraturan tersebut adalah semua bentuk pembaharuan dalam penyelenggaraan Pemerintahan Daerah. Hal ini menandakan bahwa pada prinsipnya regulasi yang mewadahi inovasi di Indonesia sudah tersedia dan pemaknaan inovasi secara formal di dalam regulasi tersebut sudah sejalan dengan konsep inovasi secara akademis. Tentunya hal ini merupakan sebuah langkah yang cukup baik dan diharapkan dapat mendukung tumbuh dan berkembangnya inovasi pada penyelenggaraan pemerintah daerah.

Selain itu, perhatian Pemerintah Pusat terhadap inovasi yang dilakukan oleh Pemerintah Daerah perlu untuk diapresiasi. Selain ketersediaan regulasi, Pemerintah Pusat juga memberikan pengakuan terhadap pelayanan publik yang inovatif. Pada bulan Juni tahun 2018 yang lalu, Tim Panel Independen Kementerian Pendayagunaan Aparatur Negara dan Reformasi Birokrasi (Kemen PANRB) mengumumkan Top 99 Sistem Inovasi Pelayanan Publik (Sivonik). Berdasarkan Pengumuman Nomor : 001/TPI.06/ 2018 tentang Top 99 Inovasi Pelayanan Publik Tahun 2018 Kompetisi Inovasi Pelayanan Publik di Lingkungan Kementerian/Lembaga, Pemerintah Daerah, Badan Usaha Miik Negara dan Badan Usaha Miik Daerah, terdapat 16 kementerian, 20 lembaga, 18 provinsi, 16 kota, dan 39 kabupaten yang masuk dalam Top 99 Inovasi Pelayanan Publik Tahun 2018.

Salah satu Pemerintah Daerah yang cukup banyak mendapatkan penghargaan adalah Pemerintah Daerah Kota Surabaya (Pemkot Surabaya). Pemkot Surabaya berhasil menempatkan tiga buah program publiknya sebagai bagian dari 99 Sivonik tersebut. Ketiga program tersebut diantaranya adalah:

1. Pelayanan publik 6 in 1 yang meliputi pengurusan akte lahir, kematian, perkawinan, 
perceraian, surat pindah datang, dan pindah keluar secara online.

2. Tahu Panas (tak takut kehujanan dan tak takut kepanasan). Program ini merupakan kegiatan perbaikan rumah tidak layak huni melalui program rehabilitasi sosial daerah kumuh.

3. Pahlawan Ekonomi dan Pejuang Muda. Program ini merupakan program pemberdayaan ekonomi bagi Ibu Rumah Tangga dan para Pemuda yang putus sekolah.

Tentunya program yang diputuskan dan dilaksanakan oleh Pemerintah Daerah Kota Surabaya ini perlu untuk mendapatkan apresiasi secara akademis sebagai bagian dari Inovasi Daerah. Oleh karenanya, tulisan ini dimaksudkan untuk mengeksplorasi pendapat akademis mengenai inovasi sektor publik serta menyediakan tinjauan reflektif terhadap tiga program inovatif yang diterapkan oleh Pemerintah Daerah Kota Surabaya dilihat dari perspektif konseptual tipologi inovasi sektor publik.

\section{Identifikasi Pembahasan}

Tulisan mengulas konsep dan teori tentang inovasi pada sektor publik, dengan mengangkat pembahasan mengenai:

1. Apakah yang dimaksud dengan inovasi dan inovasi sektor publik?

2. Apa saja tipologi inovasi sektor publik dan bagaimanakah tinjauan reflektif terhadap tiga program Inovasi Pelayanan Publik Pemerintah Daerah Kota Surbaya berdasarkan tipologi inovasi sektor publik?

\section{Tujuan Penulisan}

Tulisan ini bertujuan untuk mengeksplorasi konsep dan teori mengenai inovasi, inovasi sektor publik dan tipologi inovasi sektor publik serta tiga inovasi pelayanan publik yang dilaksanakan oleh Pemerintah Daerah Kota Surbaya.

\section{Metode Penulisan}

Berdasarkan pertanyaan yang akan dibahas, maka tulisan ini disusun dengan menggunakan desain eksplorasi. Gabrielian menjelaskan bahwa maksud dari metode eksplorasi adalah: "the central purpose of exploratory design is to develop valid definitions of a concept, describe a process, or yield beginning theories that explain the phenomenon under study" (Gabrielian, 1999). Dengan desain ini diharapkan dapat diperoleh pemahaman yang valid mengenai inovasi, inovasi sektor publik dan tipologi inovasi sektor publik serta dihasilkan tinjauan reflektif terhadap tiga program inovasi pelayanan publik yang dilaksanakan oleh Pemerintah Daerah Kota Surbaya dengan menggunakan kacamata tipologi inovasi sektor publik.

Sedangkan data dan informasi yang ditampilkan di dalam tulisan ini merupakan data sekunder yang kemudian dianalisis secara heuristik berdasarkan apa yang terungkap secara implisit pada data dan informasi dimaksud.

\section{Kerangka Konseptual}

\subsection{Konsep Dasar Inovasi}

Pertanyaan yang tentu perlu dijawab di bagai awal pembahasan ini adalah: Apakah yang dimaksud dengan inovasi? Hingga saat ini, beberapa ahli mencoba untuk menjelaskan konsep dasar inovasi. Salah satu penjelasan mengenai konsep inovasi tersebut disampaikan oleh Ackoff yang menyatakan bahwa inovasi merupakan antitesis dari perilaku seperti mesin (Ackoff, 1981). Pernyataan Ackoff tersebut mengisyaratkan bahwa inovasi adalah keberanian untuk menunjukkan perilaku yang keluar dari kebiasaan yang itu-itu saja. Dengan kata lain inovasi dapat dipahami sebagai sebuah perilaku yang berorientasi pada kebaruan. Dalam konteks ini yang perlu kita perhatikan bahwa Ackoff menekankan inovasi sebagai sebuah tampilan perilaku.

Dalam tulisan lainnya, konsep inovasi dipahami secara lebih kompleks seba- 
gaimana yang disampaikan oleh Kline \& Rosenberg (1986). Kedua penulis tersebut menyatakan bahwa:

Innovation is complex, uncertain, somewhat disorderly, and subject to changes of many sorts. Innovation is also difficult to measure and demands close coordination of adequate technical knowledge and excellent market judgment in order to satisfy economic, technological, and other types of constraints - all simultaneously. The process of innovation must be viewed as a series of changes in a complex system not only of hardware, but also of the market environment, production facilities and knowledge and the social contexts of the innovation organization.

Dari uraian Kline \& Rosenberg, hal pertama yang perlu kita pahami mengenai inovasi adalah sesuatu yang kompeks, tidak pasti, tidak terlalu tertata dan tunduk terhadap berbagai macam perubahan. Dengan kata lain, inovasi merupakan sebuah proses yang sifatnya acak, dinamis dan berorientasi pada perubahan.

Kemudian, hal kedua yang perlu juga diperhatikan bahwa inovasi sulit untuk diukur dan membutuhkan koordinasi yang melekat terkait pengetahuan yang sifatnya teknis dan penilaian yang baik dari pengguna produk organisasi dengan tujuan memuaskan atau memenuhi berbagai tuntutan termasuk ekonomi, teknologi dan tuntutan yang lainnya secara bersamaan. Pernyataan ini menjelaskan bahwa membutuhkan sebuah upaya yang intensif dan berkelanjutan untuk memastikan sebuah perilaku termasuk dalam kategori inovasi. Selain itu ditegaskan pula bahwa inovasi terkait dengan upaya untuk mengatasi berbagai keterbatasan sumberdaya.

Hal terakhir yang perlu dicatat bahwa inovasi harus dipahami sebagai rangkaian perubahan dalam sebuah sistem yang kompleks, tidak saja menyangkut hal-hal yang sifatnya terlihat seperti fasilitas fisik yang digunakan di dalam organisasi tetapi juga lingkungan pasar, pengetahuan dan fasilitas produksi dan konteks sosial dari inovasi organisasi. Pernyataan ini kembali menegaskan bahwa inovasi adalah perubahan sistemik yang komprehensif.

Dalam tulisan yang lain Fuglsang \& Pedersen menyatakan bahwa setidaknya inovasi berhubungan dengan dua hal yaitu: (1) melakukan sesuatu yang baru dan (2) mengembangkan sesuatu yang baru tersebut dapat berjalan sesuai dengan konteksnya (Fugslang \& Pedersen, 2011). Pengertian yang disampaikan Fugslang \& Pedersen menekankan pada penciptaan kebaruan dan bagaimana kebaruan tersebut dapat berjalan secara efektif dan efisien.

Berdasarkan sejumlah pengertian tersebut maka kita dapat melihat pola yang cukup umum dalam konsep inovasi bahwa inovasi berhubungan dengan kebaruan atau berorientasi pada kebaruan. Sehingga inovasi dalam tulisan ini dipahami sebagai penciptaan kebaruan baik dari aspek masukan, proses maupun keluaran dari organisasi serta hasilnya memberikan implikasi (dalam jangka pendek) dan dampak (dalam jangka panjang) yang positif bagi pemangku kepentingan.

\subsection{Inovasi Sektor Publik}

Setelah kita memahami konsep inovasi, selanjutnya kita akan mengelaborasi konsep Inovasi Sektor Publik. Sudah cukup banyak ahli yang menulis konsep dasar inovasi sektor publik. Salah satunya adalah Lynn yang menjelaskan bahwa inovasi (dalam organisasi pemerintah) merupakan transformasi dari fungsi utama organisasi dan perubahan yang permanen dan mendasar dalam struktur organisasi (Lynn, 1997). Selain itu, penulis lainnya yaitu Albury menjelaskan bahwa inovasi sektor publik merupakan kreasi dan implementasi baru pada aspek proses, produk, pelayanan dan metode penyampaian yang memiliki implikasi dampak yang signifikan pada 
efektivitas, efisiensi dan kualitas (Albury, 2005).

Dalam tulisan yang berbeda, Mulgan menyatakan bahwa inovasi sektor publik merupakan ide atau gagasan baru yang dapat diterapkan di sektor publik dan ide-ide tersebut hendaklah merupakan ide yang baru minimum sebagiannya baru dan berguna (Mulgan, 2007).

Berdasarkan sejumlah konsep inovasi sektor publik yang telah disinggung di atas, maka terdapat pola yang umum yang dapat kita lihat yaitu membicarakan perubahan yang dapat diterapkan secara efektif dalam proses, produk, pelayanan dan metode penyampaian pelayanan kepada masyarakat.

\subsection{Tipologi Inovasi Sektor Publik}

Hal lain yang dapat kita elaborasi lebih lanjut adalah mengenai tipologi inovasi sektor publik. Setidaknya terdapat 6 buah tipologi inovasi sektor publik (Halvorsen, Hauknes, Miles, \& Roste, 2005), yaitu:

1. Penciptaan pelayanan yang baru atau pengembangan sebuah pelayanan. Misalnya pengembangan layanan kesehatan reproduksi remaja di Puskesmas.

2. Inovasi proses yang menekankan pada perubahan cara dalam menghasilkan sebuah pelayanan atau produk tertentu. Misalnya menggunakan mesin yang mencetak nomor antrian bagi pasien yang hendak mengambil obat di apotik.

3. Inovasi administratif yang memfokuskan pada perubahan kebijakan. Misalnya merubah kebijakan agar lebih berorientasi pada pertumbuhan investasi melalui tax holiday.

4. Inovasi sistem yaitu perubahan pada struktur organisasi atau merubah cara kerjasama dan interaksi di dalam organisasi. Misalnya merampingkan struktur organisasi atau pimpinan organisasi mendelegasikan kewenangan kepada unit tertentu di dalam organisasi.
5. Inovasi konseptual yakni perubahan pada cara pandang dari aktor yang terlibat sehingga lebih komprehensif dalam menyelesaikan masalah. Misalnya penataan pemukiman kumuh yang tidak saja memperhatikan aspek peningkatan kualitas kesehatan, tetapi juga pemberdayaan ekonomi bagi warganya.

6. Perubahan radikal pada rasionalitas yaitu merubah cara pandang dari pemberi pelayanan. Misalnya dengan memberi penyadaran kepada aparatur pemerintah bahwa mereka hidup dari gaji yang bersumber pada pajak yang dibayarkan warganegara sehingga mereka diharuskan memberikan pelayanan yang terbaik.

Berdasarkan penjelasan mengenai tipologi inovasi sektor publik tersebut, maka kita dapat mengabstrasikannya ke dalam model berikut ini:

\section{Gambar 1}

\section{Model Tipologi Inovasi Sektor Publik}

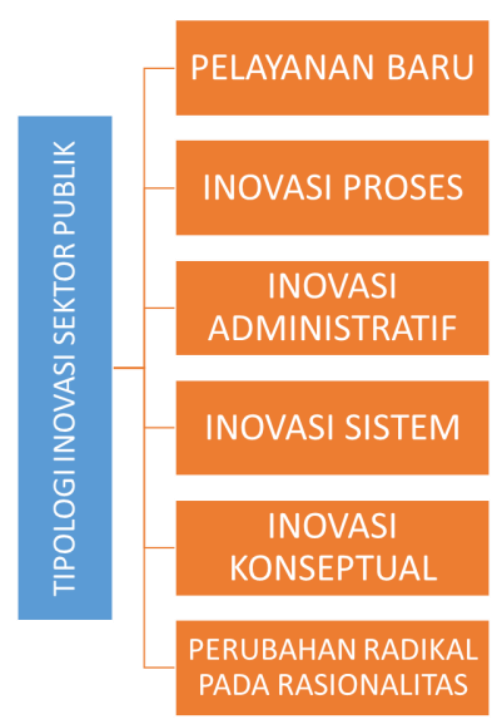

Sumber: diintepretasikan dari tulisan Halvorsen, Hauknes, Miles, \& Roste (2005)

\section{Deskripsi Singkat Tiga Program Inovasi Pemkot Surabaya}


Pada bagian ini akan diuraikan bagaimana bentuk operasional dari tiga buah program Pemkot Surabaya yang masuk ke dalam kategori Top 99 Sisvonik. Pertama adalah program 6 in 1. Dalam program ini masyarakat kota Surabaya bisa mengurus enam hal sekaligus dalam program ini secara online, yaitu akte lahir, kematian, per-kawinan, perceraian, surat pindah datang, dan pindah keluar. Melalui inovasi ini, masyarakat Kota Surabaya diuntungkan karena mereka bisa menghemat waktu, tenaga, dan biaya karena tidak perlu lagi datang ke kantor Dinas Kependudukan dan Catatan Sipil Kota Surabaya untuk mengurus keperluan 6 jenis layanan administratif tersebut. Meski demikian, peran serta RT/RW tetap tidak ditinggalkan. Lebih lanjut dapat diketahui bahwa untuk mengurus akte perceraian dan pernikahan, jika sudah tersedia surat dan doku-mentasinya maka masyarakat bisa meng-gandakan dokumen tersebut lalu mengung-gahnya kedalam aplikasi yang telah disediakan Pemkot Surabaya. Aplikasi tersebut sudah bisa diakses melalui aplikasi telpon pintar mulai dari tahun 2017. Perlu untuk diketahui bahwa pada dasarnya aplikasi ini sebenarnya sudah lama dikembangkan secara online dengan menggunakan alat semacam kartu Anjuang-an Tunai Mandiri (ATM). Tetapi untuk saat ini sudah dapat diakses dengan meng-gunakan handphone.

Kedua adalah inovasi Tahu Panas (tak takut kehujanan dan tak takut kepanasan). Program ini merupakan program yang dikembangkan oleh Dinas Sosial Kota Surabaya. Bentuknya merupakan perbaikan rumah tidak layak huni dan pembangunan jamban sehat melalui program rehabilitasi sosial daerah kumuh. Penanganan program ini dilakukan secara terpadu, baik dalam hal perbaikan fisik, lingkungan, sosial maupun ekonomi masyarakat di lingkungan perkampungan. Program Tahu Panas pada prinsipnya sudah berjalan sejak tahun 2003 dan tiap tahunnya terus mengalami peningkatakan.

Ketiga adalah inovasi Pahlawan Ekonomi dan Pejuang Muda yang berfokus pada pemberdayaan ibu rumah tangga dari keluarga miskin dan pejuang muda. Tujuan dari program ini adalah mengakselerasi pengentasan kemiskinan. Secara operasional, tindakan yang diambil oleh Pemkot Surabaya adalah menghidupkan mesin kedua, yaitu para istri atau ibu-ibu rumah tangga pada keluarga miskin manakala penghasilan suami mereka belum mencukupi untuk memenuhi kebutuhan keluarga. Sedangkan untuk anak muda yang putus sekolah atau tidak melanjutkan ke perguruan tinggi, tapi masih punya keinginan untuk meningkatkan kesejahteraan ekonominya ke taraf yang lebih baik, maka Pemkot Surabaya memfasilitasinya dengan program yang dinamakan Pejuang Muda. Para peserta Pahlawan Ekonomi dan Pejuang Muda akan diarahkan untuk mengembangkan bisnis Usaha Kecil dan Menengah (UKM), mulai dari pelatihan, hingga pendampingan sampai ke tahap pengemasan, promosi dan pemasaran produk. Program ini sudah terbukti dapat mengangkat taraf perekonomian warga Kota Surabaya. Berdasarkan keterangan yang disampaikan oleh Walikota Surabaya bahwa untuk saat ini pendapatan paling rendah warga Surabaya yang dulunya mencapai angka $34 \%$ sudah berhasil ditekan menjadi tinggal $8 \%$ saja. Sedangkan pendapatan menengah yang dahulunya $40 \%$ dan pendapatan tinggi $14 \%$, saat ini sudah berubah komposisinya. Untuk kategori pendapatan tinggi sudah mencapai $41 \%$ dan sisanya yakni $51 \%$ adalah pendapatan menengah (Surabaya, 2018).

\section{Tinjauan Reflektif Tiga Program Inovasi Pemkot Surabaya dari Sudut Pandang Tipologi Inovasi Sektor Publik}

Pada bagian ini, kita akan mencoba untuk melakukan tinjauan reflektif terhadap tiga program inovatif yang dilaksanakan oleh Pemda Kota Surabaya dengan menggunaan kacamata tipologi inovasi sektor publik. Program inovatif yang pertama adalah program 6 in 1. Sebagaimana yang sudah dijelaskan sebelumnya program ini merupakan program di bidang pelayanan administrasi kependudukan. Kita dapat melihat bahwa Pemerintah Kota Surabaya mencoba untuk meningkatkan kapasitas aplikasi teknologi informasi yang dimilikinya ke 
tingkatan yang lebih mutakhir menyesuaikan dengan perkembangan teknologi yang ada di dalam masyarakat. Hal ini ternyata sangat membantu peningkatan pelayanan yang diberikan kepada masyarakat karena semakin mudah diakses. Apabila kita merujuk pada karakteristik inovasi, maka program 6 in 1 termasuk pada tipologi inovasi proses. Hal ini dikarenakan yang terjadi dalam Program 6 in 1 adalah perubahan pada cara Pemkot Surabaya dalam menyampaikan pelayanan kepada masyarakatnya. Sebelumnya, pelayanan 6 in 1 dapat diakses oleh warga Kota Surabya dengan cara menggunakan kartu ATM atau harus berkunjung secara langsung ke Dispendukcapil Kota Surabaya. Namun, sekarang dengan peningkatan kapasitas aplikasi teknologi informasi, maka warga cukup mengurus keperluan pelayanan administratifnya dengan mengunggah dokumen yang dibutuhkan melalui aplikasi berbasis telpon pintar (smartphone) sehingga menjadi lebih praktis dan mudah cari sisi cara menggunakan layanan.

Program inovatif kedua yang akan dibahas adalah program Tahu Panas yang merupakan singkatan dari tak takut kehujanan dan tak takut kepanasan. Program ini dilaksanakan dengan cara melakukan perbaikan rumah tidak layak huni dan pembangunan jamban sehat melalui program rehabilitasi sosial daerah kumuh yang diintegrasikan dengan pemberdayaan ekonomi. Berdasarkan hal tersebut, maka inovasi yang terdapat pada program Tahu Panas termasuk ke dalam tipologi inovasi konseptual. Hal ini disebabkan inovasi yang dilakukan pada program Tahu Panas ditujukan untuk melakukan perubahan pada cara pandang dari aktor yang terlibat sehingga lebih komprehensif dalam menyelesaikan masalah. Sebagaimana yang diketahui bahwa program ini tidak semata-mata merubah pemukiman penduduk agar lebih sehat dan layak huni, tetapi juga merubah cara pandang pemerintah bahwa setelah pemukiman kumuh diubah menjadi pemukiman yang sehat dan layak huni, masyarakat yang ada di dalamnya juga perlu diperhatikan tingkat kesejahteraan ekonominya. Oleh karenanya, kemudian Pemerintah Daerah
Kota Surabaya melaksanakan program pemberdayaan ekonomi agar penyelesaian masalah yang dihadapi oleh Penduduk di pemukiman kumuh dapat diselesaikan secara lebih komprehensif.

Program inovatif terakhir yang akan didiskusikan pada bagian ini adalah Program Pahlawan Ekonomi dan Pejuang Muda. Program ini dilaksanakan dengan cara melaksanakan pemberdayaan ekonomi bagi Ibu Rumah Tangga dari keluarga miskin dan para pemuda putus sekolah guna mengembangkan bisnis UKM, mulai dari pelatihan, hingga pendampingan sampai ke tahap pengemasan, promosi dan pemasaran produk. Inovasi ini dapat dikategorikan sebagai bentuk tipologi inovasi penciptaan layanan baru sebab Pemerintah Daerah Kota Surabaya membuat sebuah program pelayanan baru berupa pemberdayaan ekonomi yang secara spesifik ditujukan bagi kelompok sasaran tertentu yakni Ibu Rumah Tangga dari keluarga miskin dan para pemuda putus sekolah. Secara simultan program ini juga memenuhi tipologi inovasi administratif karena jika ditinjau dari sisi dampaknya, Pemerintah Surabaya mencoba mengalihkan konsentrasi kebijakannya dari kelompok masyarakat ekonomi dengan daya beli menengah ke arah masyarakat dengan daya beli rendah. Penurunan angka kemiskinan yang cepat selama program ini berlangsung dari angkat $34 \%$ menjadi $8 \%$ adalah bukti bahwa program ini memiliki daya perubahan yang akseleratif dengan fokus yang jelas.

\section{Kesimpulan}

Berdasarkan uraian yang sudah diulas di atas, maka dapat disimpulkan bahwa:

1. Konsep inovasi berelasi dengan kebaruan atau berorientasi pada kebaruan. Sehingga inovasi dapat dipahami sebagai kreasi kebaruan baik pada masukan, proses maupun keluaran organisasi serta hasilnya memberikan implikasi dan dampak yang positif.

2. Inovasi sektor publik merupakan gagasan perubahan yang berorientasi pada kebaruan serta diimplementasikan dalam merubah, 
membenahi dan meningkatkan kualitas masukan, proses, penyampaian dan produk barang dan jasa di sektor publik sehingga memiliki dampak yang positif bagi peningkatan kualitas kehidupan dan kesejahteraan masyarakat.

3. Karakter tipologi inovasi sektor publik terdiri dari inovasi penciptaan dan pengembangan pelayanan, inovasi proses, inovasi administrasi, inovasi konseptual dan perubahan radikal pada rasionalitas.

4. Pemerintah Daerah Kota Surabaya memiliki tiga program inovatif yang masuk ke dalam kategori 99 Top Sistem Inovasi Pelayanan Publik yang digagas oleh Kemen PANRB. Berdasarkan tinjauan reflektif diketahui bahwa ketiga program tersebut menenuhi beberapa bagian dari tipologi inovasi sektor publik.

a. Program 6 in 1 memenuhi kategori tipologi inovasi proses karena terjadi perubahan pada cara Pemkot Surabaya dalam menyampaikan pelayanan kepada masyarakatnya yakni dari kunjungan langsung dan Kartu ATM untuk mengurus 6 layanan administratif menjadi cukup mengunggahnya di dalam aplikasi berbasis smartphone.

b. Program Tahu Panas termasuk ke dalam tipologi inovasi konseptual karena program ini tidak semata-mata merubah pemukiman penduduk agar lebih sehat dan layak huni, tetapi juga merubah cara pandang pemerintah daerah bahwa setelah pemukiman kumuh diubah menjadi pemukiman yang sehat dan layak huni maka perlu perlu diperhatikan tingkat kesejahteraan ekonominya melalui program lanjutan berupa pemberdayaan ekonomi sehingga masalah diatasi secara komprehensif.

c. Program Pahlawan Ekonomi dan Pejuang Muda yang termasuk ke dalam tipologi inovasi penciptaan layanan baru sebab Pemerintah Daerah Kota Surabaya menerbitkan pelayanan baru berupa pemberdayaan ekonomi yang ditujukan bagi Ibu Rumah Tangga dari keluarga miskin dan para pemuda putus sekolah. Secara bersamaan program ini juga memenuhi tipologi inovasi administratif karena dampaknya mampu menekan angka penduduk dengan penghasilan rendah dari $34 \%$ menjadi $8 \%$.***

\section{Bibliografi}

Ackoff, R. (1981). Creating The Corporate Future: Plan or Be Planned For. John Willey and Sons.

Albury, D. (2005). Fostering Innovation in Public Services. Public Money and Management, 51-56.

Freeman, C. (1997). The Economic of Industrial Innovation. London: Routledge.

Fugslang, L., \& Pedersen, J. S. (2011). How Common is Public Sector Innovation and How Similiar is It to Private Sector Innovation? Dalam V. Bekkers, J. Edelenbos, \& B. Steijn, Innovation In the Public Sector: Linking Capacity and Leadership (hal. 44-60). New York: Palgrave MAcmillan.

Gabrielian, V. (1999). Qualitative Research Methods: An Overview. Dalam G. J. Miller, \& L. M. Whicker, Handbook of Research Method in Public Administration (hal. 184). New York: Marcel Dekker, Inc.

Halvorsen, T., Hauknes, J., Miles, I., \& Roste, R. (2005). Innovation in the Public Sector: on the Differences between Public and Private Sector Innovation. Oslo: Publin.

Hughes, O. E. (2003). Public Management and Administration: An Introduction. New York: Palgrave Macmillan. 
Kline, S., \& Rosenberg, G. (1986). An Overview of Innovation: The Possitive Sum Strategy. Washington, DC: National Academy Press.

Land, G., \& Jarman, B. (1992). Breakpoint and Beyond: Mastering The Future Today. Harper Collins Publisher.

Lynn, L. (1997). Innovation and the public interest: Insight form the Private Sector. Dalam A. A. Altshuler, \& R. D. Behn, Innovation in American Government: Challenges, Opportunities, and Dilemmas (hal. 83-103). Washington, DC: The Brookings Instituions.

Mulgan. (2007). Ready or Not? Taking Innovation in the Public Sector Seriously. Dalam NESTA Provocation.

Mulyono, F. (2008). Inovasi di Sektor Publik. Jurnal Administrasi Publik, 130-144.

Osborne, D., \& Geabler, T. (1992). Reinventing Government: How the Entrepreneurial Spirit Is Transforming the Public Sector. Reading, MA: Addison-Wesley.

Surabaya, A. B. (2018, Juli 19). Humas Surabaya. Diambil kembali dari Bangga Surabaya:

https://humas.surabaya.go.id/2018/07/19 /3-terobosan-surabaya-masuk-top-99sistem-inovasi-pelayanan-publikkemenpan-rb/

Suwarno, Y. (2008). Inovasi di Sektor Publik. Jakarta: STIAN-LAN Press.

Suwarno, Y. (2011). Inovasi di Sektor Publik. Diambil kembali dari zerosugar.files. wordpress.com: https://zerosugar.files.wordpress.com/20 11/03/inovasi-sektor-publik.pdf 


\section{PEDOMAN PENULISAN}

1. Naskah berupa hasil kajian hasil penelitian dalam bidang administrasi publik.

2. Naskah belum pernah diterbitkan oleh media lain baik dalam maupun luar negeri, panjang tulisan antara 15-20 halaman kuarto (A4) dengan font times new romans.

3. Naskah harus disertai dengan abstraksi. Jika menggunakan bahasa Indonesia maka abstraksi dalam bahasa inggris sedangkan jika bahasa inggris abstraksi dalam bahasa Indonesia

4. Naskah sebaiknya mencantumkan kata kunci (keywords) sebanyak 3-5 kata.

5. Sistematika penulisan yang dapat digunakan untuk hasil penelitian adalah sebagai berikut:

a. Judul

b. Abstraksi disertai kata kunci

c. Pendahuluan meliputi latar belakang, perumusan masalah dan tujuan penelitian

d. Kajian teori dan hasil penelitian terdahulu yang relevan

e. Metode penelitian

f. Hasil dan pembahasan

g. Simpulan dan saran

h. Daftar pustaka

6. Garis besar penulisan untuk artikel berupa hasil pemikiran maupun review teori adalah sebagai berikut:

a Judul

b Abstraksi disertai kata kunci

c Pendahuluan meliputi latar belakang, perumusan masalah dan tujuan penelitian

d Kajian literatur

e Pembahasan

f Hasil dan pembahasan

g Simpulan dan saran

h Daftar pustaka

7. Pustaka acuan disajikan mengikuti urutan alphabet, tahun terbit ditempatkan setelah nama pengarang;

○ Michael Hill \& Peter Hupe. 2008. Implementing Public Policy. London. Sage Publication.

- Robert B. Denhardt and Janet Vinzant Denhardt. 2006. The New Public Service: Serving Rather Than Steering. Public Administration Review, Vol. 60, No. 6 (Nov. Dec., 2000), Hal. 549-559.

8. Redaksi berhak mengedit tata bahasa dan ejaan naskah yang dimuat tanpa bermaksud mengurangi tulisan. 